\title{
Disputed State, Contested Hospitality: Dutch Ambassadors in Search of a New Overlord at the French Court of King Henry III, 1584-1585
}

\author{
BRAM VAN LEUVEREN
}

Bram van Leuveren is Lecturer in Arts, Culture, and Media Studies at the University of Groningen. His research focusses on the salient role of the performing arts and ceremonial protocol in supporting diplomatic relations between France and its most important European associates in the late sixteenth to seventeenth centuries, including England, Spain, and the Low Countries. His first monograph, Early Modern Diplomacy and French Festival Culture, 1572-1615, based on his doctoral research at the University of St Andrews, is under contract with Brill.

\begin{abstract}
In December 1584, the States-General of the Union of Utrecht dispatched a special embassy to Paris to offer King Henry III of France the titular rule of their estates. Henry was to replace Philip II of Spain, the legitimate overlord of the seventeen provinces, whom the States-General had deposed in July 1581 in direct violation of the sacred institution of the monarchy. Although largely overlooked by historians, the special embassy provides a fascinating insight into the intricate European ramifications of the Union of Utrecht's search for overlordship prior to the foundation of the Dutch Republic in April 1588. This article focuses on the divided reception of the special embassy to France from the perspective of the Union of Utrecht, especially among the powerful nobility of Holland, many of whom shared anti-French sentiments, and from the vantage point of the English and Spanish ambassadors in Paris, who tried to either intervene or obstruct the Dutch-French negotiations in a bid to alter Europe's balance of power to their advantage. By bringing together dispatches and the reported reactions of Dutch, English, and Spanish emissaries that
\end{abstract}

DOI 10.18352/emlc.146 - URL: http://www.emlc-journal.org

Publisher: Stichting EMLC, supported by Utrecht University Library Open Access Journals | The Netherlands Copyright: The Author(s). This work is licensed under a Creative Commons Attribution-NonCommercial 4.0 International License. 
have not been studied in detail before, and never alongside each other, this article argues that Henry III's calculated and pragmatic use of diplomatic ceremony played a defining role in managing the fraught relations between France and the Union of Utrecht, Spain, England, and the other Catholic powers at the French court.

Keywords: diplomacy, court ceremony, Henry III, Union of Utrecht, Dutch Revolt, England, France, Spain 


\title{
Disputed State, Contested Hospitality: Dutch Ambassadors in Search of a New Overlord at the French Court of King Henry III, 1584-1585
}

\author{
BRAM VAN LEUVEREN
}

In September 1580, the States-General, the legislative body of the Union of Utrecht, created François de Valois, Duke of Anjou (1555-1584), Prince and Lord (Prince et Seigneur) of their estates, except for the provinces of Holland and Zeeland. ${ }^{1}$ The title required the duke to protect the Union of Utrecht from the violent oppression of their Habsburg overlord, Philip II of Spain (1527-1598), whom the States-General would depose one year laterin direct violation of the sacred institution of the monarchy - by the Act of Abjuration (Plakkaat van Verlatinge) of July 1581. ${ }^{2}$ The Union of Utrecht was signed between 1579 and 1580 by the provinces of Friesland, Gelderland, Groningen (including Ommelanden), Holland, Utrecht, Overijssel (including Drenthe), and Zeeland to support the Dutch rebellion against Habsburg Spain. The statelets of Brabant, Flanders, and Tournaisis were largely sympathetic toward the alliance. The Union of Utrecht soon began to disintegrate, however, as many strategic towns were captured or besieged by Spanish armies, notably Breda (July 1581), Tournai (October 1581), Ypres (April 1584), Bruges (May 1584), Ghent (September 1584), Mechlin (March 1585), and - most famously - Antwerp (August $1585) .^{3}$

Anjou had been recommended to the States-General as the new overlord of the provinces by Prince William I of Orange (1533-1584), leader of the Dutch Revolt against Philip II. Orange hoped to use the young duke, heir presumptive to the French throne, as

1 The title had been bestowed upon Anjou in the Treaty of Plessis-lès-Tours: Holt, The Duke of Anjou, 134-140; Duquenne, L'Entreprise, 65-82. Between 1578 and 1579, the Duke held a similar title as Defender of the Liberty of the Low Countries Against the Tyranny of the Spaniards and Their Allies (Défenseur de la liberté belgique contre la tyrannie des Espagnols et de leurs adhérants). For more on his enterprise in the provinces, see Müller and Diegerick (eds.), Documents concernant les relations; Holt, The Duke of Anjou, 93-112; Duquenne, L'Entreprise. All dates in this article are given in New Style; Old Style dates in English sources have been converted. I would like to thank Violet Soen, David van der Linden, and the anonymous reviewer for their indispensable feedback on this article, and Margriet Hoogvliet for pointing me into the direction of the Dutch embassy to Paris.

2 Groenveld, 'Mislukte matiging', 139-140; Mout, Plakkaat van Verlatinge; Brood and Kubben (eds.), The Act of Abjuration; Haan, 'La Réputation'.

3 Hart, The Dutch Wars of Independence, 12-13. 
a pawn in his strategy to strengthen ties with France and start building an anti-Habsburg alliance in Europe. ${ }^{4}$ As is well known, Orange's diplomatic schemes failed to materialise. Anjou died of tuberculosis in June 1584, while Orange was killed by a Catholic fanatic one month later at his court in Delft. The provinces had thus lost the two figureheads of the rebellion against Philip II. This setback, along with the advance made by the Habsburg Governor-General Alexander Farnese (1545-1592) in the reconquista of Flanders and Brabant, made it necessary to search for foreign protection once again. ${ }^{5}$

After long and intense negotiations, the States-General turned to Anjou's brother, King Henry III of France (1551-1589), and in late December 1584 a special embassy was sent to Paris to offer the monarch the nominal rule of all the provinces, including Holland and Zeeland. Historians of the early modern Low Countries, France, and Spain have largely overlooked the episode. ${ }^{6}$ There are two reasons that may explain this lack of interest. First, the special embassy was ultimately unsuccessful and thus did not, in retrospect, have a particularly visible nor long-lasting impact on European history. By the end of March 1585, after protracted negotiations with the Dutch envoys, Henry III refused the States-General's offer of overlordship. Acceptance would not only have forced him into a full-scale war with Spain, but it would have sparked the military aggression of the Catholic League, a group of ardent French Catholics supported by Philip II. ${ }^{7}$ Second, the special embassy is often regarded by historians as a failed 'experiment' that merely serves to illustrate the transition of the rebellious provinces to a more innovative, republican form of government. ${ }^{8}$ After all, the Dutch search for overlordship in December 1584 was still motivated by the traditional ideal of a monarchical government. This ideal was soon abandoned by the States-General themselves when the failed mission to Paris - and the equally disappointing governorship of Robert Dudley, Earl of Leicester (1532-1588) - prompted the legislature in April 1588 to assert its rule of the northern provinces independently. ${ }^{9}$ As Randall C.H. Lesaffer has succinctly put it, the provinces became 'a Republic without a prince'. ${ }^{10}$

Johannes B.J.N. de van der Schueren, the late nineteenth-century editor of various historical documents relating to the special embassy, was the first to draw attention to the

4 For Orange's diplomatic relations with France, see Mout, 'Het intellectuele milieu', 619-622; Delen, Het hof van Willem van Oranje, 224-227; Tol, 'William of Orange in France'.

5 Soen, 'Reconquista and Reconciliation'. Farnese's recapture of Flanders and Brabant was largely facilitated by aristocrats such as Charles of Croÿ (1560-1612), Governor of Bruges, who had turned away from the Orange coalition: Soen, 'Les limites du devoir de révolte'.

6 The embassy is briefly referenced, and mostly implicitly, in Groenveld, 'Mislukte matiging', 148; Strong, 'Festivals', 46; Israel, The Dutch Republic, 46; Ochoa Brun, Historia de la diplomacia española, vi, 289; Randall, 'A Short Legal History of the Netherlands', 41. Notable exceptions are De van der Schueren (ed.), Brieven, II, 443-537, 539-558, and Geevers, 'The King Strikes Back', 86-89, discussed below.

7 Jensen, Diplomacy and Dogmatism; Vázquez de Prada, Felipe II y Francia, 239-330; Descimon and Ruiz Ibañez, Les Ligueurs de l'exil; Jouanna, La France du XVI siècle, 573-586.

8 Groenveld, 'De institutionele en politieke context', 55.

9 Groenveld, 'Mislukte matiging', 139-140; Groenveld, 'De institutionele en politieke context', 55; Groenveld, “"Verlatinge”', 66-68; Randall, 'A Short Legal History', 44, 46. Simon Groenveld's book chapter on changing concepts of sovereignty in the provinces ('North-Netherlandish Sovereigns') is forthcoming. I am grateful to the editors for allowing me to read the chapter prior to publication.

10 Lesaffer, 'A Short Legal History', 44. 
national and international significance of the episode. His transcriptions and brief editorial commentary on the surviving documents of the embassy's heading delegate, Aernt van Dorp (c. 1528-1600), have revealed the enormous diplomatic importance that the mission held in the nine months following the deaths of Anjou and Orange in the summer of 1584. ${ }^{11}$ The States-General, on their part, hoped that the special embassy would ensure the survival of the provinces as a conglomerate state independent from Philip II and renew relations with France, whose support as one of Europe's most powerful kingdoms was essential to improve the deplorable international reputation the legislature enjoyed as a rebel government. ${ }^{12}$

As the source edition by De van der Schueren suggests, the diplomatic importance of the mission was also recognised by Spain, which was keen to regain control over the provinces. On an international level, too, England, Savoy, and the Holy See in Rome instructed their visiting and resident ambassadors in Paris to keep a close watch on the special embassy. They realised that French acceptance of Dutch overlordship would create an anti-Habsburg front in Europe and thus significantly alter the balance of power on the continent. Despite his pioneering scholarship on late sixteenth-century Dutch diplomacy, De van der Schueren was clearly motivated by nationalist concerns. In the preface to his source edition, he noted that he had intentionally disregarded any historical material that did not immediately uncover 'the state of the Fatherland in the second half of the sixteenth century, or [...] the important events that took place then' ${ }^{13}$ This article, by contrast, will take on board a wider range of archival sources, including material that reveals the microhistory of diplomatic ceremonies and interactions at the late sixteenth-century French court, as well as records written in languages other than Dutch, namely English and French.

More recently, Liesbeth Geevers has discussed the diplomatic motives of the mission and the controversy surrounding the stay of the Dutch ambassadors at the French court from the viewpoint of Habsburg Spain, which saw the rebellion as a politically and confessionally motivated secessionist conflict. ${ }^{14}$ Although brief, her analysis has revealed the important role that France's diplomatic ceremony played in managing relations with the States-General, and Spain in particular. Geevers shows that Philip II had instructed his resident ambassador in Paris, Bernardino de Mendoza (c. 1540-1604), to closely report on the manner in which the Dutch envoys were received at the French court and complain to Henry III whenever he considered their reception to be too generous, considering their status as rebellious subjects of the Spanish crown. ${ }^{15}$ Geevers argues that between 1581 and 1609 , the degree of diplomatic ceremony awarded to representatives of the States-General

11 De van der Schueren (ed.), Brieven, II, 443-537, 539-558.

12 Junot, 'Pratiques et limites', 345. Following Frowein, 'Die Entwicklung', 147, Groenveld and Geevers note that European powers would only officially recognise the Union of Utrecht as an independent state if their legitimate overlord, Philip II, would recognise the States-General as a new sovereign: Groenveld, "'Verlatinge"', 68, 70; Groenveld, 'North-Netherlandish Sovereigns'; Geevers, 'The King Strikes Back', 82.

13 De van der Schueren (ed.), Brieven, I, xv: 'den toestand des Vaderlands in de $2^{\mathrm{e}}$ helft der $16^{\mathrm{e}}$ eeuw, of [...] de belangrijke gebeurtenissen, die toen plaats grepen'. All translations in this article are the author's.

14 Geevers, 'The King Strikes Back'.

15 Geevers, 'The King Strikes Back', 87-89. 
at the French and other European courts had a great influence on the state of diplomatic relations between these courts and Habsburg Spain. Favourable treatment of Dutch embassies was taken as an insult and led to the Spanish putting pressure on the hosting court to change their policy, whereas more circumspect treatment, or the outright refusal to welcome Dutch ambassadors, would serve to strengthen Spain's relations with a particular court. ${ }^{16}$

This article retains Geevers's focus on diplomatic ceremony, but analyses the special embassy to France within the broader context of international relations. It examines the divided reception of the mission, from the perspective of the Union of Utrecht, especially among the powerful nobility of Holland, many of whom shared anti-French sentiments, and from the vantage point of the English and Spanish ambassadors in Paris. These diplomats tried to either intervene or obstruct the Dutch-French negotiations in a bid to alter Europe's balance of power to their advantage. Of particular interest is the remarkable leeway permitted by Henry III to enable the visit of the Dutch train despite the international backlash. It will be argued that regardless of the fact that the diplomatic status of the provinces was not recognised by Habsburg Spain and contested by most other European states, Henry refused to treat the Dutch envoys as full-on rebels. ${ }^{17}$ The French king was well aware of their allegiance to his late brother and the advantages attached to supporting the Dutch Revolt against Spain, namely the reduction of Habsburg domination in Europe. It will be shown that the king thus sought to maintain a delicately balanced position of being hospitable toward the Dutch train while trying not to offend the diplomatic community in Paris or become the subject of international ridicule for his generous behaviour toward purported rebels and heretics.

By studying the special embassy from the perspective of diplomatic ceremony and international relations, this article seeks to contribute to existing scholarship on DutchFrench relations in the late sixteenth century. Research on the topic has been pioneered by Philip Benedict in 1999 with a comparative essay collection on the Dutch Revolt and the French Wars of Religion..$^{18}$ Although the volume gives scant attention to diplomatic ceremony and negotiation, Benedict shows that the political situation of the Low Countries and France in the second half of the sixteenth century was intimately intertwined and carried direct implications for the political situation of Europe at large. Building on the work of Benedict, Jonas van Tol has recently examined the shared interests of the provinces and France in their respective politico-religious conflicts through the diplomatic network of William I of Orange. He reveals that Orange had already been successfully investing in long-lasting contacts with the French court since the late 1560s through his diplomatic missions, transnational correspondence networks, and military campaigns. ${ }^{19}$ These contacts helped to develop extensive bilateral relations between the provinces and France that were independent from Habsburg Spanish overlordship.

16 Geevers, 'The King Strikes Back', 84.

17 For more on the problematic diplomatic status of the provinces, see Heringa, De eer en hoogheid van de staat; Geevers, 'The King Strikes Back', 81-95.

18 Benedict et al. (eds.), Reformation, Revolt and Civil War.

19 Tol, 'William of Orange in France'. 
This article complements Benedict's and Van Tol's research by focussing on DutchFrench relations in the interim period following the deaths of Anjou and Orange, and bringing into the discussion the importance of diplomatic ceremony for those and other interstate relations in Europe. As Geevers rightly suggests, consideration of diplomatic ceremony is often absent in scholarship on the constitutional, legislative, and general political history of the Low Countries. ${ }^{20}$ Groenveld and Lesaffer in particular have done valuable research on the larger legal developments that triggered the Dutch Revolt and helped to establish the later Dutch Republic, but they have not considered the role that ceremony played in specific diplomatic interactions of the States-General with foreign powers and the extent to which the hospitality awarded to representatives of the legislature determined its agency and negotiation power as a diplomatic stakeholder. ${ }^{21}$ This article, then, seeks to raise pertinent questions about the complicated, and often fraught, relationship between the diplomatic ceremony of the French court and the diplomatic agency of the Dutch ambassadors in the years 1584-1585. With what kind of ceremony was the special embassy received in Paris, at a time of great uncertainty about both the future of the Union of Utrecht and the implications that the revolt against Spain would carry for international relations? How did Henry III's reception of the Dutch envoys affect their position as negotiators? And, finally, how was the mission and the hospitality granted to the delegation perceived by the Dutch emissaries themselves and the other European ambassadors at court, in particular the English and Spanish representatives? It is hoped that these questions are of interest to scholars working on both the late sixteenth-century history of the Low Countries and France, and the cultural-diplomatic history of early modern Europe at large.

The article is divided into three parts. The first part discusses the preparation for the special embassy by the States-General, and the mixed reception it received, especially among the high nobility of Holland on whose support for the mission the legislature was mostly dependent. It examines how the noblemen perceived relations with France in the late sixteenth century and envisaged the future of the provinces in Europe in very different ways. The second part explores the troublesome journey of the Dutch envoys to Paris and the efforts of Henry III to keep their official reception at his court as secret as possible. By analysing the welcome of the Dutch ambassadors alongside the coincidental arrival of an English embassy, the section demonstrates the differences in diplomatic agency and the extent of hospitality to which the provinces, as a disputed king-less state, and England, as a recognised sovereign state, were entitled. The article's final part examines the equally complicated stay of Van Dorp's train in Paris and unpacks the heated reactions that their presence evoked from the other foreign ambassadors at court, by bringing together dispatches and the reported reactions of Dutch, English, and Spanish emissaries.

20 Geevers, 'The King Strikes Back', 94, n. 28.

21 Groenveld, De kogel door de kerk?; Groenveld, 'De institutionele en politieke context'; Groenveld, "'Verlatinghe"'; Lesaffer, 'A Short Legal History'. 


\section{Tense Diplomatic Negotiations at Home}

In December 1584, each of the eight provinces represented in the States-General selected their most competent and respected men to join the special embassy. ${ }^{22}$ Holland, the most wealthy and authoritative province, delivered the head of the delegation, Aernt van Dorp. As Lord of Teemsche, Maasdam, and Middelharnis, Van Dorp had been a favourite of the late Orange in various advisory, military, and diplomatic functions, and was thus deemed the most suitable nobleman to lead the mission to France. In the summer of 1568, Van Dorp had joined Orange on his first military campaign in Brabant and became part of his inner circle in the 1570s. As Governor of Zierikzee and Zeeland Beoostenschelde, Van Dorp successfully defended the Island of Schouwen against Spanish forces (1575-1576) and participated in the peace talks with Philip II's ambassadors at Breda in 1575. In 1578 he had also represented Orange in negotiations with Anjou about the military defence of the provinces, and with the Habsburg crown about the possibility of a Dutch-Spanish peace. ${ }^{23}$

Zeeland, the second-most prosperous and powerful estate, was represented by its Treasurer-General Jacob Valcke (d. 1603). Utrecht, in turn, nominated Johan Rengers tot Arentshorst (d. 1646), the province's deputy in the Council of State, and Amelis van Amstel van Mynden tot Cronenburgh (1531-1593), the Councillor of the High Court of Holland and Zeeland. Brabant sent Cornelis van Aarsens (1545-1627), the States-General's registrar, Jan Hinckart, Lord of Ohain (c. 1525-1585), the postmaster of Antwerp, and Richard vi van Merode, Lord of Oorschot (1550-1587). Gelderland, moreover, dispatched Gerhard Voeth (d. 1607), the province's Councillor, as well as Elbert de Leeuw (c. 1519-1598) and Johan van Gent, Lord of Ooijen (c. 1530-1613). Flanders selected Noël de Caron, Lord of Schoonewal (c. 1550-1624), while Friesland was represented by Hessel van Aysma (1527-1592), President of the Court of Friesland, and Jelger van Feytsma (d. 1620), member of the Provincial-Executive of Friesland. ${ }^{24}$ Mechlin, finally, appointed Antoine de Lalaing, Seigneur de La Mouillerie (d. 1585), Quintijn Taffin, Sieur de la Prée, who acted as the treasurer of the special embassy, and Lieven Calvaert, who served as a scribe to Van Dorp. ${ }^{25}$

22 Jan Wagenaar offers a compelling narrative of the organisation of the States-General in the chaotic days after Orange's assassination: Wagenaar, Vaderlandsche Historie, vIII, 3-9. On the varying number of provinces that sent delegations to the assemblies of the States-General in the early 1580 s, see Thomassen, Instrumenten van de macht, 75-80.

23 De van der Schueren (ed.), Brieven, I, xiii-xlix, 246-54. Van Dorp's negotiations with Anjou resulted in the duke's instalment as Defender of the Liberty of the Low Countries Against the Tyranny of the Spaniards and Their Allies on 13 August 1578 (see note 1 above). The peace talks with the Spanish Habsburgs, represented by Don John of Austria (1547-1578), the Governor-General of the provinces, proved fruitless as a result of John's uncompromising attitude and his premature death in October 1578.

24 Caron would serve as an agent for the States-General in England from 1591 to 1609 and as a resident ambassador in that same country from 1609 to 1624 .

25 The names of the deputies are given in Van Meteren, Belgische ofte Nederlantsche historie, fol. 226. Calvaert was one of the first agents, and possibly the first, for the provinces in France: Van der Aa and Van Harderwijk (ed.), Biografisch Woordenboek der Nederlanden, III, 34-35. 
The provinces deemed Henry III a suitable candidate to become their new overlord for various reasons. In the instructions for the special embassy, dated 3 December 1584, the States-General formulated the justification for his nomination as follows:

And because of the death of His Highness [Anjou], Prince and Lord of these provinces, they are left vacant and returned to the disposition of the said States [States-General], and because the King of Spain with his supporters has not stopped waging war against them and cruelly invading and oppressing them, they have found it both just and naturally right to take refuge and throw themselves into the arms of His Majesty [Henry] to be joined to the Kingdom of France, from which these provinces, or the greater part of them, were originally split and separated. ${ }^{26}$

Since Anjou had served as Prince and Lord of the provinces, it was considered self-evident that the duke's titular rule would pass on to his elder brother Henry. ${ }^{27}$ Although left unstated in the instructions for the Dutch ambassadors, the States-General probably realised that Henry's status as King of France would enable him to advance their diplomatic interests more effectively than Anjou. The kings of France ranked high in the European hierarchy of princes and their authority would help to boost the international standing of the maligned provinces and expand their diplomatic influence abroad. ${ }^{28}$

Additionally, Henry's inherited title of Most Christian King (Rex christianissimus or Roi très-chrétien), which had been granted to the kings of France by the papacy in the twelfth and thirteenth centuries as a token of their efforts during the crusades, made him one of the most recognised authorities in Catholic Europe, aside from the pope himself. ${ }^{29}$ Henry's title could thus help to protect the Dutch from anti-Calvinist violence abroad. Finally, the States-General anticipated that Henry would accept their offer of overlordship in good conscience if they reminded him that the provinces were once part of the Kingdom of France. The legislature alluded here to the Burgundian rule of the provinces which had been cemented in June 1369 with the marriage of Philip the Bold (1342-1404), founder of the Valois dynasty, the royal house of France of which Henry was the last surviving male descendant, to Margaret of Male, Countess of Flanders (1350-1405). ${ }^{30}$ Their assertion that the provinces had been 'split and separated' from France's influence undoubtedly referred to the annexation and inheritance of various Burgundian possessions by Maximilian of

26 The Hague, Nationaal Archief (hereafter NA), Archief Staten-Generaal, 1576-1588, 86D, Instructions for the special embassy to France, 3 December 1584, article 4: 'Et comme par le trespaz de Son Alteze, Prince et Seigneur des dictes Provinces, icelles sont vaccantes et retournees en la disposition des dictz Estatz et que le Roy d'Espaigne avec ses adherens ne cesse de continuer la guerre et les cruellement invahir et oppresser, ont trouve convenir selon Justice et Droict de nature de prendre leur refuze, et se jecter entre les bras de Sa $\mathrm{M}^{\text {te }}$ pour estre joinctz au Royaulme de France, dont originellement lesdictes Provinces ou la pluspart d'icelles sont este esclichées et separees.' Excerpts of the instructions are printed in Japikse (ed.), Resolutiën der Staten-Generaal, IV, 495-501.

27 Liesbeth Geevers notes that the instructions never mentioned the Act of Abjuration and rightly suggests that 'perhaps the Dutch feared Henry III might be offended by it': Geevers, 'The King Strikes Back', 87. In other words, the States-General were keenly aware of their widespread reputation as a rebel government and did not want Henry to refuse their offer of overlordship on account of their perceived disobedience as royal subjects.

28 The papal order of precedence, promulgated under Julius II in 1504 and still carrying weight at the Catholic courts of the late sixteenth century, ranked the king of France as fourth among the European rulers after the pope himself, the Holy Roman Emperor, and the king of Rome: Nys, 'Histoire du droit international', 515-516.

29 Holt, The French Wars of Religion, 8-10.

30 Lesaffer, 'A Short Legal History', 36-37. 
Habsburg (1459-1519) in the late fifteenth century after his marriage to Mary of Burgundy (1457-1482) in August 1477. ${ }^{31}$ The States-General thus hoped that Henry might be enticed to claim that the provinces were essentially French property, accept the Dutch offer of overlordship, and bring a definitive end to Habsburg Spanish rule in the Low Countries..$^{32}$

Despite expressing high hopes for Henry as future overlord, the States-General clarified in their instructions that rulership of the provinces did not entail unconditional sovereignty. The legislature wished to protect the sovereign authority of each of the eight provinces of the Union of Utrecht as had been the case during Anjou's titular rule in the late 1570 s to early 1580 os. $^{33}$ This authority, as Simon Groenveld explains, was exercised by the assemblies of the estates 'within their own [province]'. ${ }^{34}$ The States-General thus offered Henry a 'bridled' or 'curtailed' sovereignty that allowed the French king limited powers only, especially with regard to the military defence of the estates, while safeguarding the franchises, privileges, and liberties of the legislature. ${ }^{35}$ Therefore, most articles of the instructions to the Dutch ambassadors carefully specified the affairs over which the States-General wished to have a final say, including the exercise of the Protestant religion, the costs of the war against Habsburg Spain, the bilateral relations with England, and the garrisoning of towns. ${ }^{36}$

Notwithstanding the minimal influence that the position of overlord offered with regard to domestic affairs, the noble representatives of Holland in particular were adamant that Henry would abuse his titular rule of the provinces. The States of Holland, which had an influence beyond its mere single vote within the States-General, feared that the French king would conspire with Philip II, a fellow Catholic, to return the Calvinist Dutch to their legitimate ruler at the cost of the political autonomy of the provinces. ${ }^{37}$ Three years before, many of these noblemen had opposed the nominal rule of Anjou on similar grounds and believed that a partnership with Protestant England would offer a better alternative, while others feared that any offer of overlordship to a ruler other than Philip II would be sacrilegious. ${ }^{3}$ The States-General was heavily reliant on the support of the noble representatives of Holland if it was to dispatch the special embassy to France. It was crucial, therefore,

31 NA, Staten-Generaal 1576-1588, 86D, Instructions for the special embassy to France, 3 December 1584, article 4: 'esclichées et separees'. Lesaffer, 'A Short Legal History', 37.

32 Thiry and Van Bruaene, 'Burgundian Afterlives', have argued that the Burgundian past of the provinces was also frequently invoked by various Dutch authorities in the late 1570 s and early 1580 , in order to justify the overlordship of Anjou. Van Bruane has further noted that during his ceremonial entry into Antwerp in February 1582, Anjou was associated with Philip the Good (1396-1467), who, just like the Burgundian duke, was supposed 'to bring the Low Countries under one rule again and forge national unity': Van Bruane, 'Spectacle and Spin', 273. On the States-General's instructions, see also Geevers, 'The King Strikes Back', 86-87.

33 For the strict conditions under which the States-General accepted Anjou's overlordship, see Holt, The Duke of Anjou, 128-129; Gelderen, The Political Thought, 179-180; Duquenne, L'Entreprise, 63-79.

34 Groenveld, 'North-Netherlandish Sovereigns'.

35 Gelderen, The Political Thought, 180; Groenveld, 'North-Netherlandish Sovereigns'.

36 NA, Staten-Generaal 1576-1588, 86D, Instructions for the special embassy to France, 3 December 1584, articles $12,34,43$, and 48, respectively. Van Dorp, too, noted that Henry would only be accepted as overlord of the provinces 'under certain conditions' ('onder zeker condicien'): De van der Schueren (ed.), Brieven, II, 450 (30 September 1584).

37 De van der Schueren (ed.), Brieven, II, 443; Aalbers, 'Factieuze tegenstellingen', 412-413; Groenveld, Wagenaar, and Meer, 'Pre-Napoleonic Centralization', 50, 55-57; Groenveld, 'North-Netherlandish Sovereigns'.

38 Groenveld, 'Spanje in de aanval', 145-146, 148; Van Bruaene, 'Spectacle and Spin', 263-264. 
that Van Dorp, who headed the mission on Holland's behalf and firmly backed Henry's nomination as future ruler of the provinces, won their support.

On 30 September 1584, Van Dorp delivered a speech to the Knighthood and Nobility of Holland and West Frisia, a prestigious assembly of provincial aristocrats that directly advised the States-General, in order to convince the dissatisfied nobles of the diplomatic need to offer the nominal rule of the estates to the French king. ${ }^{39}$ The surviving text of the speech, which Van Dorp seems to have read during the actual assembly of the knighthood and may have been intended for publication, provides a unique and detailed insight into the misgivings of the Dutch opponents of the special embassy to France. ${ }^{40}$ Van Dorp summarised those misgivings as follows:

The Frenchman is unfaithful, deceitful, and intolerable in his ruling; is, moreover, an enemy of the Reformed religion. He may have an understanding with the King of Spain, so as to keep his Huguenots under his control once he has handed us over [to Philip II]. Similarly, the Queen of England [Elizabeth I] shall become an enemy of these lands [the provinces] because of the alliance with the Frenchman, due to which commerce and the herring trade will perish. ${ }^{41}$

By invoking the purportedly treacherous nature of the French monarchy, Van Dorp undoubtedly hinted at the Saint Bartholomew's Day Massacre of 24 August 1572, which many Dutch noblemen and Protestants elsewhere in Europe found impossible to forget. Rumour had it that Henry, then Duke of Anjou, had been instrumental in arranging the deaths of Admiral Gaspard de Coligny (1519-1572) and the other Huguenot leaders which led to the carnage. ${ }^{42}$ Van Dorp tried to counter those anti-French sentiments by suggesting that kings 'who for this age have behaved themselves well and modestly in their ruling' were virtually non-existent. ${ }^{43}$ The envoy believed that Henry was in fact well-disposed to France's Protestant minority, because he had intentionally avoided a 'new war' with the Huguenot stronghold of La Rochelle and cemented an alliance with 'all [Swiss] cantons', including Geneva which harboured a large number of Huguenot refugees. ${ }^{44}$

39 For the political influence of the knighthood in the States of Holland and the States-General, see Koopmans, De Staten van Holland en de Opstand; Aalbers, 'Factieuze tegenstellingen'. See also Geraerts, Patrons of the Old Faith, 7, 9, for a general account of the socio-economic and political privileges of provincial knighthoods in the Low Countries.

40 NA, Archief familie Van Dorp, 992, Speech by Aernt van Dorp to the Knightgood and Nobility of Holland and West Frisia, 30 December 1584; De van der Schueren (ed.), Brieven, II, 445-455. Van der Schueren believes that the text for Van Dorp's speech had been written by someone else, but that the notes following the speech, which summarise the final decision of the knighthood to elect Henry as overlord of the provinces, had been drafted by the envoy himself during the assembly.

41 De van der Schueren (ed.), Brieven, II, 447: 'Den Fransman is ontrou, bedriechlick ende in zijn regeringe onverdrachlick; is oick viant vande gereformeerde religie; hij mach verstant hebben met den Coninck van Spaignen, om, ons overgelevert hebbende, zijne Hugenoten beter tot zijnen wil te mogen crigen; item de Coninginne van Ingelant zal, overmits daccord metten Fransman, viant werdden van dese landen, waerdeur coop- ende harinckvaert te nyette zoude ghaen.'

42 Knecht, The French Wars of Religion, 48; Holt, The French Wars of Religion, 84-85.

43 De van der Schueren (ed.), Brieven, II, 450: 'die voor dees tijt hen goit ende eenvoudlich gedragen hebben in heure regeringe'.

44 De van der Schueren (ed.), Brieven, II, 450-451: 'nieuv oirloge'; 'alle de Cantons'. The alliance that Van Dorp referred to here is the Treaty of Soleure, concluded on 8 May 1579, which Henry renewed on 22 July 1582: Fazy, Genève, 122-123. 
Van Dorp then went on to contradict rumours about France's secret contacts with Habsburg Spain. He argued that, as longstanding foes, the kingdoms had always tried to outdo one another, either 'in private or public', and were thus not secretly allied. ${ }^{45}$ In addition, Van Dorp did not believe that the English forces would pose a threat to the welfare of the Union of Utrecht. He predicted that if Elizabeth I took up arms, she would be forced to declare war against France, 'our protector', a prospect that Van Dorp deemed highly unattractive from the queen's point of view considering the enormous costs involved. ${ }^{46}$

Indeed, Elizabeth was another popular candidate for the vacancy of overlord of the provinces, as she privately supported the States-General in their war against Habsburg Spain by sending gunpowder, weapons, and horses. ${ }^{47}$ Moreover, the Protestant queen had provided shelter to the Calvinist Dutch refugees who fled from the notorious Spanish inquisition in the $1560 .^{48}$ Van Dorp, however, foresaw serious problems with Elizabeth as titular head of state. Both her gender and advancing age (having turned fifty-one on 7 September 1584) made her a particularly unsuitable candidate, for the queen would not be able to produce an heir and her death would only entail 'belligerence and change' in Europe. ${ }^{49}$ Furthermore, Elizabeth's ongoing conflict with Queen Mary Stuart of Scotland (1542-1587) would further complicate her overlordship in the provinces. As any nominal ruler of the estates would be required to do upon their appointment, openly declaring war on the Habsburg Spanish crown would inevitably worsen civil unrest in England, as Philip II was a prominent supporter of Queen Mary and her Catholic followers.

Van Dorp's speech to the Knighthood and Nobility of Holland and West Frisia brings into focus the mixed reception the special embassy received when presented to some of the more influential members of the States-General, as well as the alternative future some of them envisaged for the provinces in Europe, particularly with regard to an alliance with England. The speech may also help to explain why even Van Dorp's own embassy seems to have been divided over the mission. On 21 December 1584, shortly before the deputies were to take their leave at the port town of Brill, Leonard Casembroot (d. 1604), one of the noblemen selected for the mission by the States of Holland, reported to Van Dorp that he was too ill to take part. Van Dorp later referred to 'the illness of gentleman Casimbroot, which to the judgement of some is surely English', meaning he believed that it was a sham..$^{\circ}$ Van Dorp's wry remark indeed suggests that Casembroot, and with him possibly other members of the delegation, were more inclined to seek refuge under Elizabeth's Protestant wing rather than Henry's Catholic one.

45 De van der Schueren (ed.), Brieven, II, 452: 'bedectelick oft opentlick'.

46 De van der Schueren (ed.), Brieven, II, 453: 'onsen protecteur'. On Elizabeth's involvement in Dutch-Spanish relations, see Giry-Deloison, 'Elisabeth Ire'; 'Giry-Deloison, 'France and Elizabethan England', 223-225'.

47 Wilson, Queen Elizabeth, 27-41; Groenveld, "'Verlatinge”, 70.

48 Haan, 'La Réputation', 124, 127-128.

49 De van der Schueren (ed.), Brieven, II, 447: 'crijchsonrust ende veranderinge'.

50 Van Dorp to Gecommitteerde Raden, Brill, 22 December 1584, in De van der Schueren (ed.), Brieven, II, 493:

'De ziecte vanden heer Casimbroot, die naer dimaginatie van eenige wel Ingels mochte wesen.' 
Van Dorp ultimately managed to convince the members of the knighthood that Henry ought to be nominated as overlord..$^{51}$ The salient role that Van Dorp had played in the household of the late Orange as advisor and confidant to the prince undoubtedly helped to add weight to his argument, as did his past achievements in the revolt against Habsburg Spain and the diplomatic activities of the provinces. With Van Dorp heading the mission, then, the States-General also sought to renew the extensive diplomatic relations that Orange had built with France since the 1560s. ${ }^{52}$ However, Spain's increasing consolidation of Brabant and Flanders over the summer of 1584 was most probably the decisive factor in the knighthood's agreeing to the special embassy to France, as both estates were desperate for foreign support and expected that Henry would readily offer military protection against Philip II. ${ }^{53}$ While Spanish forces laid down a siege of the Flemish city of Antwerp that summer, which would last until the next year, all hopes were vested in Van Dorp's mission to restore peace and eliminate Habsburg control of the provinces for good. ${ }^{54}$

\section{Eventful Journey and Diplomatic Delays}

While the Knighthood and Nobility of Holland and West Frisia had struggled to agree to Henry's nomination as overlord of the provinces in the first instance, Van Dorp's mission faced another challenge, namely arriving at the Parisian court on time. Although the deputies intended to take their leave around 18 December 1584, they were delayed by the Duke of Parma (1529-1589), the Spanish Governor-General of the Low Countries, who had obstructed their plan to bring fourteen warships from Zeeland to the harbour of Brill. Parma reportedly threatened to use violence against the deputies, which serves as a reminder that the Spaniards anxiously monitored the whereabouts of the States-General's representatives en route to Paris. ${ }^{55}$ To make matters worse, unfavourable winds forced the ambassadors to postpone their departure until the next year, much to the chagrin of Roch de Sorbiers, Sieur des Pruneaux (d. 1596), the French agent who had earlier negotiated with the States-General about the Dutch mission. ${ }^{56}$

51 This was decided at the end of the assembly: NA, Archief familie Van Dorp, 992, Speech by Aernt van Dorp to the Knighthood and Nobility of Holland and West Frisia.

52 Tol, 'William of Orange in France'.

53 Van der Schueren (ed.), Brieven, II, 443-444; Groenveld, 'Spanje in de aanval', 148.

54 Antwerp eventually surrendered on 17 August 1585, five months after the return of Van Dorp's delegation to the provinces.

55 Japikse (ed.), Resolutiën der Staten-Generaal, IV, 509, Draft resolution of the States-General, 19 December 1584. Violet Soen describes how Juan de Vargas Mexía, Spanish ambassador in Paris from 1577 to 1581, closely followed any interaction between the aristocracy of the Low Countries and the French court, and members of the Montmorency family in particular: Soen, Vredehandel, 13, 138, 142, 170, n. 2.

56 Japikse (ed.), Resolutiën der Staten-Generaal, IV, 509, Draft resolution of the States-General, 21 December 1584. Geevers 'The King Strikes Back', 89, notes that one positive outcome of the special embassy was Henry's appointment of Pruneaux as agent to the States-General in late March 1584, but this was probably a recognition a posteriori. Pruneaux had served Anjou as his diplomatic representative in meetings of the States- General from 1578 until the duke's death in 1584: Duquenne, L'Entreprise, 29. 
Having mollified Pruneaux with letters of apology, the deputies finally set sail for Dieppe on 3 January 1585 in a squadron of warships delivered by the States-General. ${ }^{57}$ About a week later, however, headwinds forced the envoys to land at Boulogne harbour after which they travelled to Abbeville and Clermont. ${ }^{58}$ Only in Clermont did they receive a letter from Henry specifying the nature of their reception. In it, the king requested that the emissaries forebear from entering Paris but instead wait for fifteen days at Senlis, a town located forty kilometres to the north of the capital. Henry provided no further details. ${ }^{59}$ As the king's request was the first letter that the Dutch embassy had received from the French on their journey, which enforced a sojourn far from the court in Paris, Van Dorp may be forgiven if he interpreted the document as a bad sign. Whether the delegate saw his embassy's wait at Senlis as simply rude, or perhaps as a punishment for the Dutch revolt against Philip II, and what the French crown would have perceived as the sacred institution of the monarchy, action was plainly required.

The Dutch envoys quickly dispatched letters to the various royals and nobles in Paris with whom they were on good terms, requesting them to act favourably at the French court on their behalf. Their letters had already been written in early December 1584 and were addressed to Henry de Navarre (1553-1610), the titular head of the Huguenots in France, to Pierre de Melun, Prince of Épinoy (1550-1594), who had supported Orange in his war against Spain, and to Catherine de' Médici (1519-1589), mother of Henry III, who had occupied a powerful role as regent and governor to her sons and had acted favourably toward her Protestant subjects in the past. ${ }^{60}$ These pleas for support demonstrate that Van Dorp's embassy realised that diplomatic hospitality from their hosts at the French court was not a given, but needed to be earned and negotiated.

It appears that Van Dorp had not immediately briefed the States-General about the enforced delay of his embassy at Senlis, instead waiting until he had arrived in Paris by mid-February before he reported to the Gecommitteerde Raden of Holland that he had been inconvenienced. ${ }^{61}$ According to Van Dorp, Henry had delayed the reception of the Dutch embassy to allow for the impending arrival of an English delegation, headed by Henry Stanley, Earl of Derby (1531-1593). Derby's embassy had travelled to Paris to invest Henry into the Order of the Garter, England's highest order of chivalry, that was meant to reinforce bonds of loyalty

57 Hooft, Nederlandsche historien, vi, 261.

58 This was presumably on 11 January: Van Meteren, Belgische ofte Nederlantsche historie, fol. 126.

59 Hooft, Nederlandsche historien, vi, 262.

60 States-General to Navarre, Melun, and Catherine de' Médici, The Hague, 3 December 1584, in De van der Schueren (ed.), Brieven, II, 460-464. Épinoy had also accompanied Anjou in 1583 while travelling through France. As Governor of Mechlin and Tournaisis, he belonged to one of the most important noble families of the provinces and was affiliated with the French court through his marriage with Hippolyte de Montmorency-Bours (d. 1618) in 1586. For more on the role of the Melun family in the Dutch Revolt, see Soen, Vredehandel, 133. On Catherine de' Médici, see Cloulas, Catherine de Médicis; Knecht, Catherine de’ Medici; Crouzet, Le Haut Cour. 61 Van Dorp's first draft of the report is dated 15 February 1585; a second, slightly altered draft, is dated one week later. Both drafts are kept in NA, Van Dorp, 1001. The second draft is printed in De van der Schueren (ed.), Brieven, II, 504-513. The footnotes in the latter source indicate the parts where the second draft deviates from the first one. The last letter of the Dutch embassy to the States-General before their enforced sojourn in Senlis was sent from Abbeville on 19 January 1585: NA, Staten-Generaal 1576-1588, 89A. 
between the English monarchy and its allies. ${ }^{62}$ Van Dorp explained the reason for his delayed response, and thus for the enforced wait of his embassy at Senlis, as follows:

The reason why I have not informed you any sooner, Sirs, is because I believed that under the pretext of respect [the French] wanted to gain time while waiting for the arrival from England of Mylord Derby, accompanied (as they said) by two hundred Noblemen. They travelled straight to Saint-Denis, and will be received here in the city [of Paris] with much pomp the day after tomorrow [13 February]; if not, there remains the fear that this delay [of Van Dorp's letter] might have a very different meaning than would be appropriate for our common cause. ${ }^{63}$

The dispatch is rather hard to follow, owing to its rhetoric of diplomatic courtesy, but seems to suggest that Van Dorp was unaware of the exact reason of his embassy's delayed reception when he was first instructed by the king to wait at Senlis. ${ }^{64}$ For this reason, Van Dorp may have decided to postpone briefing the Gecommitterde Raden about the proceedings of his embassy for fear that the wait at Senlis would be interpreted by the legislature not as a diplomatic necessity, but as a suspicious detour that would endanger the successful completion of the secret mission. This is probably what Van Dorp meant by the phrase 'the fear that this delay might have a very different meaning than would be appropriate for our common cause'. ${ }^{65}$ The ambassador thus offered his apologies to the members of the Gecommitteerde Raden, all of whom were eagerly awaiting to hear the opinion of Henry about the States-General's offer of overlordship, for not having corresponded any sooner.

In the letter, Van Dorp also showed himself aware that the delayed reception was not necessarily meant as an insult to his delegation but as a diplomatic measure to avoid a clash with the visit of Derby's embassy. Henry, of course, feared that the delayed arrival of the Dutch envoys at Boulogne harbour would unintentionally put the controversial mission of Van Dorp in the spotlight, rather than draw attention to Derby's entry which was to celebrate Anglo-French relations 'with much pomp'. ${ }^{66}$ Van Dorp's comments on his delayed reception seem to be substantiated by a report of the English embassy in France, written by Derby and his right-hand Edward Stafford (1552-1605) on 6 February 1585 and intended for Queen Elizabeth. The report claimed that on 6 February Henry had instructed the English diplomats to stay at Clermont, a town located eighty kilometres to the north of Paris,

62 For more on the stay of the English diplomats and the ensuing festivities at the French court, see Strong, 'Festivals'.

63 Van Dorp to Gecommitteerde Raden, Paris, 22 February 1585, in De van der Schueren (ed.), Brieven, II, 506: 'D'oorsaecke, waeromme oick uwer Ed. tselve nyet eer verwitticht en hebbe, is geweest vuyt meninge dat men onder tdexel van devotie den tijt heeft willen winnen, binnen welcken hier vuyt Ingelandt verwacht is de bijcompste van mylord Dherby, verselschapt (zoomen zeyt) van twe hondert Edelmannen. Denselven is rechtevoort tot Sint Denys, ende zal overmorgen hier te stede zeer statelijck ontfangen worden; ende anders ist naegelaeten vuyt vrese, off dit vuytstel anders hadde mogen geduydet worden, dan onse gemeene saecke wel oirbaer waer.'

64 According to Hooft, Nederlandsche historien, VI, 262, the reason for the delay was communicated to the Dutch envoys at the time by Pruneaux, but I have not been able to find further evidence for this in the archives. 65 Van Dorp to Gecommitteerde Raden, Paris, 22 February 1585, in De van der Schueren (ed.), Brieven, II, 506: 'vuyt vrese, off dit vuytstel anders hadde mogen geduydet worden, dan onse gemeene saecke wel oirbaer waer'. In Van Dorp's interpretation of the events, this belief may have been reinforced further by the unforeseen high costs of the embassy, most of which, as will be seen, were to be covered by the States of Holland.

66 Van Dorp to Gecommitteerde Raden, Paris, 22 February 1585, in De van der Schueren, Brieven, II, 506: 'zeer statelijck'. 
for two more days and not to enter the capital until 13 February. ${ }^{67}$ The enforced delay of the English ambassadors, then, enabled Henry to avoid a clash with the visit of Van Dorp and his emissaries, who arrived in Paris inconspicuously on 11 February.

Henry had clearly aimed to keep the journey of Van Dorp's embassy through France as low-key as their arrival in Paris. Their reception in the various cities, towns, and burghs en route to Paris was inhospitable to say the least, especially when considering that it was customary for the French monarchy to welcome foreign ambassadors with banquets and entertainments to honour and celebrate their diplomatic relations, if not in the open than at least more privately. ${ }^{68}$ In his reports home, Van Dorp made no mention of a personal welcome at Boulogne harbour by a town's representative. The financial records of the embassy merely indicate that the deputies stayed at Boulogne's staging post until 13 January $1585 .{ }^{69}$ The English ambassadors, by contrast, were immediately greeted by the governor of Calais when they arrived in the town on 1 February, despite having been scheduled to land at Boulogne (strong headwinds still prevailed). ${ }^{70}$ Their reception was accompanied by a hefty gun salute. The following night, the ambassadors dined with the town's governor at 'a burgeses house in the market place' and enjoyed after-supper music and dancing from local ladies and gentlemen. ${ }^{71}$ In Amiens, four days later, they were met by a distinguished nobleman from the French court, François Gouffier, grand seigneur of Picardy (d. 1594), and an impressive number of ' 100 Gentlemen \& best citizens' ${ }^{72}$ Their visit was once again marked by a three-hundred-gun salute. In the evening, the English diplomats were served 'a great store of very large \& good fresh water fish, \& [...] wine of diuers sorts'..$^{73}$ This pattern of gun salutes, eating, and feasting was repeated over the next eleven days until Derby's embassy made its grand ceremonial entry into Paris on 13 February.

The surviving statements of Van Dorp's embassy on food and travel expenses indicate that the French crown did not offer the Dutch envoys any financial compensation for their journey to Paris. ${ }^{74}$ Only their accommodation at Senlis and the capital, where they were lodged in public inns in the rue Saint-Denis, was paid for by the king. ${ }^{75}$ The English deputies, on the other hand, were given spacious and 'sumptuously furnished' rooms 'for them all of the Kings cost' at the Hôtel de Longueville, a royal residence also known as the Hôtel d'Anjou. ${ }^{76}$ Food and wine 'in as great plenty as could be desired' were brought to

67 London, British Library (hereafter BL), Cotton ms Caligula E. VII, fol. 242r, Report by Derby and Stafford to Elizabeth I on their journey into France, 6 February 1585. On 20 January 1585, Stafford was created AmbassadorExtraordinary to invest Henry into the Order of the Garter: Howes, 'The King of France's Investiture', 213, n. 34 .

68 This is the topic of my PhD dissertation: Leuveren, Forging Diplomacy.

69 The record of Van Dorp's payments to Boulogne's postmaster, Nicollas du Karoy, still survives in NA, Van Dorp, 1008, January-February 1585.

70 BL, Cotton MS Caligula E. viI, fol. 242r.

71 BL, Cotton MS Caligula E. viI, fol. $241 \mathrm{v}$.

72 Howes, 'The King of France's Investiture', 215.

73 Howes, 'The King of France's Investiture', 215.

74 NA, Van Dorp, 1008, January-February 1585.

75 Van Dorp to Gecommitteerde Raden, Paris, 22 February 1585, in De van der Schueren (ed.), Brieven, II, 506. 76 Howes, 'The King of France's Investiture', 216. 
the English by the Swiss Guard. ${ }^{77}$ This disparity prompted Van Dorp's chamberlain, Martin Lengelle, who had also served in the household of the late Orange, to raise concerns about the embassy's limited budget. In early January, when the deputies passed through Abbeville, he urgently requested the States-General to provide 'the sum of four hundred livres tournois' for sending 'hundred horses [...] to the kingdom of France'. ${ }^{78}$

Lengelle's request for money was not incidental. According to the draft of a letter written by Van Dorp to the States of Holland on 9 April 1585, shortly after his return to the provinces, the costs of his ultimately unsuccessful mission were much higher than anticipated. The States urged Van Dorp to account for what was considered to be the train's excessive expenditure, a demand which the ambassador considered highly offensive. Van Dorp's letter to the States of Holland reads like an apologia, in which he tried to convince the legislature of his invaluable service to the Union of Utrecht, especially with respect to the special embassy: 'That we [Van Dorp and the other Dutch envoys] under all conditions were to protect and promote the honour and justice of this land'. ${ }^{79}$ Furthermore, Van Dorp contended that his spending of the States's exchequer was perfectly in keeping with the ambitious nature of the mission to France, since he 'had more deputies in the legation than any other' and had travelled to Paris 'in the severest part of the winter'. ${ }^{80}$

Despite their costly and tedious journey, the Dutch ambassadors enjoyed a surprisingly generous reception at Senlis on 24 January 1585, where they were welcomed by a member of the royal household, François de la Fontaine, Baron of Oignon (1566-1632). ${ }^{{ }^{1}}$ As Ordinary Gentleman of the King's Bedchamber (gentilhomme ordinaire de la Chambre $d u$ Roi), Oignon was assigned to oversee the king's correspondence within and outside France, while also representing him in negotiations with foreign princes and dignitaries. According to the Dutch chronicler Pieter Cornelisz. Hooft (1581-1647), Oignon was accompanied by a small cortège of respectable noblemen that included Pruneaux, Colonel Guillaume de Rebours, one 'Allein', and the Prince of Épinoy. ${ }^{82}$ The presence of Épinoy at the official reception suggests that the prince had accepted the ambassadors' plea for support in the letter that they had dispatched to him, and various other prominent members of the French court, from Clermont earlier that month. The noblemen then escorted Van

77 Howes, 'The King of France's Investiture', 217; BL, Cotton MS Caligula E. viI, fol. 242v.

78 Lengelle to States-General, Tournois, 16 January 1585, in De van der Schueren (ed.), Brieven, II, 502: 'la somme de quatre cens livres tournois'; 'cent chevaulx [...] au roiaulme de France'.

79 Van Dorp to the States of Holland, Paris, 9 April 1585, in De van der Schueren (ed.), Brieven, II, 542: 'dat wij slants eer ende gherechticheyt allenthalven zouden hebben te bewaeren ende voostaen'.

8o Van Dorp to the States of Holland, Paris, 9 April 1585, in De van der Schueren (ed.), Brieven, II, 543: 'als eenich andere $[. .$.$] meer gedeputeerdens inde legatie heeft gehadt'; 'int hartste vanden winter'.$

81 Oignon was also appointed seigneur of Fontaines and Berthinval and Governor of Crêpy and Pont Sainte-Maixence. Note that Oignon was a baron and thus lower in rank than an earl who would have been typically assigned by the French monarchy to receive fully accredited foreign ambassadors like Derby.

82 Hooft, Nederlandsche historien, vI, 262. Rebours was appointed seigneur of Bertrand-Fosse, Châtillon, and Prunelé. He was also Advisor to the Parisian Parliament and President at the cour des aides (sovereign court concerned with public finances), and since 1597 Councillor Ordinary. 'Allein' refers here to either Jacques de Renaud, seigneur of Alein, Aurons, and Lamanon, or his brother Guillaume, sieur of Alleins. Both were sons of Nicolas de Renaud (1455-1527), sire of Alleins and seigneur of Forcalquier. 
Dorp's delegation until 9 February after which Henry sent horses, coaches, and servants to bring the envoys to their public lodgings in Paris. ${ }^{83}$

Although their welcome at Senlis lacked the ostentatious nature of Derby's arrival to keep the nature of the special embassy secret, the fact that the Dutch ambassadors were officially received by the French monarchy in the first place was diplomatically significant. ${ }^{84}$ It demonstrated the ceremonial freedom permitted by Henry to gain the trust and sympathy of Van Dorp's embassy, despite the international outcry over their rebellious government and the diplomatic pressure from Spain to refuse the deputies any form of hospitality. The king's approach to the contested diplomatic status of the States-General was therefore clearly pragmatic. In the words of Simon Groenveld, Henry treated the provinces at Senlis 'as if they were independent', undoubtedly with the intent of flattering the Dutch emissaries and gaining their sympathy in the impending negotiations about the overlordship at court. ${ }^{85}$ By avoiding a clash with the entry of the English diplomats, then, the king could keep the reception of Van Dorp's train out of sight and direct public attention to the opulent celebrations that were planned for his investiture into the Order of the Garter. ${ }^{86}$ Henry thus struck a fine if uneasy balance between facilitating his reception of, and negotiations with, the Dutch ambassadors and keeping the international community sufficiently in the dark about his actual diplomatic motives and schemes.

\section{Reception at Court}

Henry's strategy to divert public attention was not entirely successful, because the ambassadors of the Pope, Savoy, and Spain were quick to raise their voices about his reception of the Dutch emissaries. ${ }^{87}$ The Spanish resident ambassador to France in particular was shocked when he received word about the arrival of Van Dorp's embassy at Boulogne harbour, and probably even more so when he learned about its official reception at Senlis. Bernardino de Mendoza, a former Captain-General in Spain's war against the Dutch rebels, had been dispatched to the Parisian court by Philip II in April 1584, ostensibly to commiserate on the death of Anjou, but more specifically to find out about Henry's attitude to the power vacuum in the Dutch provinces. ${ }^{88}$ The English deputies, who took an equal interest in the king's opinion on the matter, reported that Mendoza had demanded

83 Hooft, Nederlandsche historien, vi, 262.

84 Cf. Geevers, 'The King Strikes Back', 89.

85 Groenveld, "Verlatinghe", 70.

86 The arrival of the English ambassadors and the ensuing festival for Henry's investiture were indeed discussed with great interest in various chronicles, diaries, and diplomatic reports. See for example Howes, 'The King of France's Investiture'; De Thou, Historiarum, IV, 315-316; L'Estoile, Journal de L'Estoile, 276. For relevant diplomatic dispatches, see Strong, 'Festivals', 56, n. 4. No livret or recueil has been produced for the Anglo-French festival, probably for fear that it would provoke ardent French Catholics who deemed Henry's alliance with Queen Elizabeth heretical: De Thou, Historiarum, IV, 276.

87 These ambassadors were Gerolamo Ragazzoni (1537-1592), Bernardino de Mendoza, and René de Lucinge (c. 1553-c. 1615), respectively.

88 Vázquez de Prada, Felipe II y Francia, 83-84; Geevers, 'The King Strikes Back', 88-89. On Mendoza's diplomatic career in France, see Jensen, Diplomacy and Dogmatism. 
an audience with Henry no less than three times after the embassy's arrival in Boulogne. ${ }^{89}$ What was undoubtedly perceived by the Dutch envoys as an act of generosity, was considered downright offensive by the Spanish diplomat. The English ambassador Edward Stafford described Mendoza's audience with Henry on 9 January 1585 as follows:

[Mendoza] desired the King to remember that these deputies [the Dutch] were 'rebels to his master [Philip II] and heretics to the church', and therefore, considering his [Henry's] strait league with that King, he ought 'not only not to admit them to his presence nor to hear them, but also to deliver them and to send them to his master.90

Rather than meeting Mendoza's concerns, however, or approving of his characterisation of the Dutch ambassadors as rebels, Henry replied, according to Stafford, in an unusually sharp manner:

The King answered him in a great choler, that he was nobody's subject nor at commandment; that his realm was free for all comers, and his ears open to hear everybody; that as it was a common thing both for him [Henry] to hear any subject of his master's [Philip II] and to entertain diverse [visitors], and a more common thing for his master to entertain divers[e] [visitors] of his, so was it a liberty of all princes of Christendom to entertain and hear all comers as they thought good. ${ }^{91}$

As a Christian sovereign, Henry considered it his right ('a liberty') to welcome to France 'all comers' regardless of their diplomatic or sovereign status. In other words, it was 'a common thing' to receive subjects of the Spanish king, just as it was to host any other foreign deputies, including the Calvinist Dutch who were regularly perceived by the international community as outlaws. In Stafford's account of the audience, Henry carefully avoided Mendoza's use of the term 'rebels' so as not having to engage into a discussion with the Spanish ambassador, and the other foreign emissaries at court, about the diplomatic and legal status of the States-General's representatives. ${ }^{92}$ Rather, the king invoked the widespread belief among early modern writers of 'mirrors for princes' (specula principum) that every virtuous ruler should receive foreign visitors, as well as loyal subjects, with liberality or generosity. By awarding hospitality, which Henry understood as giving attention ('to hear') or providing spectacle ('to entertain'), the early modern ruler could display the magnificence of their court and show off their liberality in hosting visitors, however different in culture or religion. ${ }^{93}$

According to an anonymous Dutch account of Mendoza's audience, printed in the first volume of Pieter Bor's series of chronicles on the Dutch Revolt (published in 1679), Henry even went so far as to acknowledge that 'he did not wish to hear and receive the deputies of the Low Countries as apostate rebels of their king, but as people who were burdened,

89 Stafford to Walsingham, Paris, 12 January 1585, in Crosby (ed.), Calendar of State Papers, XIX, 228.

90 Stafford to Walsingham, Paris, 12 January 1585, in Crosby (ed.), Calendar of State Papers, XIX, 228.

91 Stafford to Walsingham, Paris, 12 January 1585, in Crosby (ed.), Calendar of State Papers, XIX, 228.

92 Compare Philip II's reception of exiled members of the Catholic League and other radical Catholics from France at his court in the 1590s: Descimon and Ruiz Ibañez, Les Ligueurs de l'exil; Lesaffer, 'Between Faith and Empire'.

93 Stafford to Walsingham, Paris, 12 January 1585, in Crosby (ed.), Calendar of State Papers, XIX, 228. Early modern ideas about princely liberality were mostly based on Aristotle, who ranked it as first among the cardinal virtues: Nicomachean Ethics, IV.1, 11; Leuveren, 'Perceptions of Privacy'. 
oppressed, and overwhelmed with injustice, and so to examine their cause'. ${ }^{94}$ Attractive as such a rehabilitation may have been to the anonymous Dutch author, who undoubtedly hoped to glorify the revolt of his fellow countrymen against Spain, it seems unlikely that Henry openly refused to label the Dutch as rebels in the presence of Mendoza, as it would have cast Philip II as oppressor. ${ }^{95}$ Such a bold move would have inevitably brought the king into a serious diplomatic conflict with Spain and its Catholic allies. This is especially true when we consider the public nature of the audience. Stafford's detailed account suggests that the envoy did not rely on hearsay but witnessed the event himself, possibly joined by other foreign diplomats who might have grouped together behind a tapestry. ${ }^{96}$

If Stafford and other diplomats at court would indeed have witnessed Mendoza's audience, it seemed to have been impossible for Henry to actually 'entertain and hear all comers as [he] thought good'. ${ }^{97}$ The power of the monarch to award strangers, even outlaws, with ceremony was thus strongly dependent on the presence or not of other envoys and visitors at court. They determined the extent to which the king could show his affection to visitors in public, because their chronicles or correspondences to heads of state played a decisive role in fashioning his image. Depending on whose account of Mendoza's audience we accept, Henry was either a disloyal ally, unwilling to return the Dutch rebels into the hands of Philip II (according to Mendoza himself), a generous king, willing to receive all visitors at court, regardless of their cultural or religious backgrounds (according to Stafford), or a defender of the Dutch cause (according to the anonymous author cited by Bor). Being highly aware of their power to make or break his international reputation, it seems more likely that Henry was careful not to speak too favourably about the Dutch envoys for fear that the other foreign diplomats at court would learn of this.$^{98}$ Instead, Henry defended his traditional duties as a Christian king to receive and entertain all kinds of strangers regardless of their diplomatic status.

When Van Dorp's embassy finally arrived at the court in Paris on 11 February 1585, tensions rose once more. Judging from Dutch and English correspondences, there were many deputies who pestered and spied on the new visitors, sometimes by sending an actual spy to infiltrate Van Dorp's embassy. Reporting on his first audience with the king one day after his arrival, Van Dorp complained that he was already regularly hindered

94 Bor, Oorspronck, begin, en vervolgh, I, 525: 'hy de gesanten van de Nederlanden niet als afvallige rebellen haers koninks: maer als overlaste/ verdrukte/ en met ongelijk overweldigde wilde horen en ontvangen/ ende hare sake examineren'.

95 The anonymous account is echoed in Van Meteren, Belgische ofte Nederlantsche historie, fol. 126, and further discussed in Wagenaar, Vaderlandsche Historie, viII, 57.

96 Hiding behind tapestries was a common strategy to overhear ostensibly private encounters at the early modern court. Marini, the French ordinary ambassador in Turin, thus sought to eavesdrop on the audience of Walter Montagu, the English agent, at the court of Carlo Emanuele I in July 1627 by hiding behind an arras: Osborne, Dynasty and Diplomacy, 120. On the tapestries at the Louvre in 1585, see Chatenet, 'Henri III au Louvre'.

97 Stafford to Walsingham, Paris, 12 January 1585, in Crosby (ed.), Calendar of State Papers, xix, 228 (emphasis added).

98 See also Stafford's account of Mendoza's audience, which, in contrast to the anonymous Dutch account cited by Bor, ends on a more diplomatic note, with Henry simply feigning ignorance about the intentions and propositions of Van Dorp's embassy: Stafford to Walsingham, Paris, 12 January 1585, in Crosby (ed.), Calendar of State Papers, XIX, 228. 
by the Catholic diplomats: 'I will not write in detail here what the ambassadors of the Pope, Savoy, and Spain, and many others, have done to first obstruct the audience and subsequently the proceedings of this business, as Your Honours can well imagine.'99 Unfortunately, Van Dorp did not specify the manner in which these ambassadors obstructed his doings at court, probably for fear that his letters would be intercepted by the diplomats in question.

The English deputies, on their part, made every effort to obtain information about the proceedings of Van Dorp's mission. By seeking to fortify relations with Henry through his investiture with the Order of the Garter, Queen Elizabeth hoped to form a joint venture with France into the provinces and produce a defensive front against the aggressive ambitions of Habsburg Spain. ${ }^{100}$ The king, however, tried to keep the actual purpose of the Dutch mission as secret as possible and refused to involve Derby and Stafford in his negotiations with Van Dorp. The English diplomats certainly did not appreciate Henry's refusal to 'make her Majesty [Elizabeth] partaker of his mind', especially considering the honour that their queen had paid Henry by investing him into the chivalric order and sending a special embassy to France to celebrate the occasion. ${ }^{101}$ On 28 February, immediately after the king's investiture ceremony, both men urged Henry to finally inform them about the details of the Dutch mission and their propositions in respect of the sender, the bringer, and the necessity of what was demanded'. ${ }^{102}$

Stafford had already sent an agent to spy on Van Dorp's delegation: Hermann Taffin, Sieur de Torsay (b. c. 1528), who had served as governor to the late military leader Filippo di Piero Strozzi (1541-1582). ${ }^{103}$ In his monthly reports to Francis Walsingham (c. 1532-1590), Stafford encoded Torsay's name in cypher to protect the governor's identity. ${ }^{104}$ Stafford's choice of Torsay was not accidental, for he was the brother of Van Dorp's treasurer: Quintijn Taffin, Sieur de la Prée, who had been elected by Mechlin to join the special embassy to France. Stafford's report of Torsay's meeting with the Dutch shortly before Van Dorp's audience with the king illustrates how wary they had become of the other deputies at court:

\footnotetext{
I [Stafford] made this man [Torsay] go to salute them [...] and tell them why I sent none [deputies] of my own, fearing they might be watched, but that I had a good will (and it was her Majesty's pleasure) to do them all the good I could. To which they answered but with reasonable cold thanks. [...] When he [Torsay] was gone, they made his brother [La Prée] swear whether he had revealed anything of their intentions; and also made one another swear solemnly that to no living creature they would disclose anything. ${ }^{105}$
}

\footnotetext{
99 Van Dorp to Gecommitteerde Raden, Paris, 22 February 1585, in De van der Schueren (ed.), Brieven, II, 508: 'Ick en sal hier nyet besunders schrijven, wat dambassadeurs vanden Paus, Savoyen, van Spaengien, met meer andere, al gedaen hebben, eerst om daudientie ende daernaer om den voortganck van desen handel te verhinderen, ghemerekt uwer E. dat selffs wel connen bedencken.'

100 Strong, 'Festivals', 45-46; Howes, 'The King of France's Investiture', 212.

101 Derby and Stafford to Walsingham, Paris, 3 March 1585, in Crosby (ed.), Calendar of State Papers, XIX, 295.

102 Derby and Stafford to Walsingham, Paris, 3 March 1585, in Crosby (ed.), Calendar of State Papers, XIX, 295.

103 Stafford to Walsingham, Paris, 22 February 1585, in Crosby (ed.), Calendar of State Papers, XIX, $276-277$.

For more on Torsay, see Picot, Les Français italianisants, I, 95-107.

104 Stafford to Walsingham, Paris, 3 March 1585, in Crosby (ed.), Calendar of State Papers, XIX, 276.

105 Stafford to Walsingham, Paris, 3 March 1585, in Crosby (ed.), Calendar of State Papers, XIX, 276-277.
} 
If the Dutch envoys suspected that even close relatives could spy on their embassy for the other foreign embassies at court, it was important not to leak anything about the secret articles that specified the conditions under which the States-General would accept Henry as their overlord. ${ }^{106}$ According to Stafford, the Dutch train failed in doing so nonetheless: '[The emissaries] keep their articles very secret and are mistrustful of everybody, except of those whom they should not trust.' 107 He then went on to describe how 'one Calvert' (Lieven Calvaert, Van Dorp's scribe and agent of the States-General in France) was looking for Pruneaux to show him the articles to be discussed during his master's audience with the king. Calvaert was apparently rather negligent in his search, for when he asked Henry de Navarre's court agents, Clervant and Chassincourt, about Pruneaux's whereabouts, he was called away by an agent of his own embassy to confess whether or not he had shown the articles to either of them. Therefore, Henry instructed Pruneaux to keep a close watch on the Dutch envoys 'to see who comes to them and whither they go'. ${ }^{108}$

Since Henry could not receive Van Dorp's embassy with ceremonial protocol in public, he was forced to hold all interactions with the Dutch behind closed doors. His audience with Van Dorp on 13 February, for example, took place in this private study ('secreet cabinet'). ${ }^{109}$ The room was one of the king's private spaces which enabled a degree of privacy and proximity between host and guest that was not normally provided in the more public spaces at court. In his report to the Gecommitteerde Raden of Holland on 22 February, Van Dorp specifically commented on the hospitality shown to him by Henry in his study: 'And your Honours can be assured that this reply [the king's initially positive response to the articles of the diplomats] was accompanied by a happy and friendly countenance.' ${ }^{110}$ Monique Chatenet has shown that just a month before, Henry had implemented a new ceremonial protocol at the Louvre that actually made it more complicated for diplomats to access the king. ${ }^{111}$ Henry had multiplied the number of antechambers to lengthen the route from the entrance hall to the audience room where he officially received visitors. Chatenet argues that the arrangements were meant to increase the solemnity of paying a visit to the king, which was considered necessary to make up for France's internal disorder, while also significantly limiting the familiarity between the monarch and his guests. Henry's invitation of Van Dorp's train to his private study was thus undoubtedly considered a great privilege by the embassy and the other diplomats at court. At the same time, the Dutch envoys probably understood that an invitation to the king's cabinet came at the expense of the public recognition that they might otherwise have sought or appreciated, just like any other foreign ambassador.

106 The articles, as they were presented to Henry, are held at NA, Staten-Generaal 1576-1588, 88, 11 February 1585 , and include the king's revisions.

107 Stafford to Walsingham, Paris, 22 February 1585, in Crosby (ed.), Calendar of State Papers, XIX, 274.

108 Stafford to Walsingham, Paris, 22 February 1585, in Crosby (ed.), Calendar of State Papers, XIX, 274.

109 Van Dorp to Gecommitteerde Raden, Paris, 22 February 1585, in De van der Schueren (ed.), Brieven, II, 507 .

110 Van Dorp to Gecommitteerde Raden, Paris, 22 February 1585, in De van der Schueren (ed.), Brieven, II, 507: 'Ende mach uwer E. wel verseeckeren, dat dees antwoorde verselschapt was met een blijde ende vriendelick gelaet.'

111 Chatenet, La Cour de France au XVI siècle, 135-140; Chatenet, 'Henri III et l'ordre de la cour'; Chatenet, 'Henri III au Louvre'. On princely access, see also Raeymaekers and Derks (eds.), The Key to Power? 
Van Dorp expressed these mixed feelings in his letter to the Gecommitteerde Raden on 22 February: 'Even if all their propositions [the interference run by the papal nuncio and the other Catholic ambassadors at court] go up in smoke, I cannot but notice that they treat us here as if we were close to their hearts, though more in secret than in public.' ${ }^{112}$ Van Dorp was therefore keen to report that, after his audience with the king, he met Catherine de' Medici and the Queen Consort, Louise de Lorraine (1553-1601), 'sufficiently public (but each separately)'. ${ }^{113}$ In other words, Van Dorp's meetings with the French royal family seem to have been just about civil enough so as not to have been offensive, while offering the Dutch envoys some form of public recognition. Despite Henry's ultimate failure to accept the offer of overlordship, the States-General probably still regarded Van Dorp's embassy as vital to the larger Dutch cause of holding out against a complete military victory of Alexander Farnese's armies in Flanders and Brabant. ${ }^{114}$ Although the Dutch emissaries had little room to interact with peers or obtain intelligence, the special embassy still garnered some public attention to promote the larger Dutch cause to the diplomatic community in Paris. The States-General may ultimately have considered the public dimension of the mission, though minimal, to be more important than whether the French king accepted their offer. ${ }^{115}$

\section{Conclusion}

The special embassy to Paris can perhaps best be seen as a diplomatic ballet that necessitated both Dutch and French parties to tread a fine line while simultaneously choreographing their next move. Before one-to-one negotiations with Henry could even commence, Van Dorp had to carefully negotiate anti-French sentiments at home, especially those of the high nobility of Holland, and facilitate agreement on the States-General's nomination of the French king as overlord of the Dutch provinces. At the French court, his negotiation position as representative of a disputed state was more obviously compromised and depended largely on the extent to which Henry was diplomatically able and willing to engage in conversation. The king himself was forced to manoeuvre between the relentless demands of the Spanish ambassador, as well as the impatient English deputies, while alternately granting and denying Van Dorp's embassy hospitality to either win their affection or give in to the diplomatic pressure of the Spanish crown and the other Catholic powers at court. The Dutch envoys, on their part, were largely forced to accept Henry's lead in this cunning dance, although their prodigious offer of overlordship kept him sufficiently

112 Van Dorp to Gecommitteerde Raden, Paris, 22 February 1585, in De van der Schueren (ed.), Brieven, II, 508: 'Alsoe alle hen voortstel in roock vergaet, zoe en can ick noch anders nyet vermercken, dan dat men ons hier metter harten meent, doch meer int secreet, dan int openbaer' (emphasis added).

113 Van Dorp to Gecommitteerde Raden, Paris, 22 February 1585, in De van der Schueren (ed.), Brieven, II, 507: 'Ghenouch int openbaer (maer elck apart)'. For more on Van Dorp's interpretation of his public and private activities at the French court, see Leuveren, 'Perceptions of Privacy'.

114 Soen, 'Reconquista and Reconciliation'.

115 Leuveren, 'Perceptions of Privacy'. On the public diplomacy campaigns of the Dutch provinces, see also Horst, De Opstand in zwart-wit; Helmers, 'Public Diplomacy'. 
interested to continue negotiations until it proved impossible to unify the French monarchy's foreign and domestic concerns in late March 1585.

More than just a metaphor for diplomatic manoeuvring, ballets at the late sixteenthcentury French court (known as ballets de cour) were in fact of keen interest to foreign ambassadors, as they regularly dramatised international relations, featured messages specific to the purpose of their embassy, and - perhaps most importantly - made them feel like they belonged to an international community of like-minded ruling elites. ${ }^{116}$ The ballet that constituted the pinnacle of the festival for Henry's investiture with the Order of the Garter (known as The King's Ballet) sought to create an international community that in many respects must have appeared to spectators as a microcosm of Europe's hierarchy of princes at that time, both on stage and in the auditorium. ${ }^{117}$ Given in the Great Hall of the Bishop's Palace in Paris on 3 March 1585, three days after the king's investiture ceremony, the pageant left little doubt about the one individual who was destined to lead France's citizens and visitors into the actual diplomatic ballet that he had rehearsed and choreographed himself. Henry appeared centre stage, wearing a mask, while he instructed the other dancers, who appear to have been young courtiers, dressed in white doublets and bejewelled hats, to form the letters of his name and that of his Queen Consort, Louise de Lorraine, in movement. ${ }^{118}$ The letter-dancing was followed by a grand ball, the signal for which was given by the king himself, in which the most respectable noblemen at court took their ladies by the hand to perform courantes and voltas, the most fashionable dances in France at the time. Meanwhile, Derby and Stafford were given prestigious seats at the upper end of the Great Hall, next to Catherine de' Medici and Louise de Lorraine, to signify the importance of Anglo-French relations to all the international spectators in the room. According to the English deputies, the ballet and especially the string music that accompanied the dancing produced 'such a consort and harmony as nothing cold be devised more pleasant and delightfull'. ${ }^{119}$

Absent from The King's Ballet were of course the Dutch ambassadors who would not have been invited to such a public occasion, given the disputed nature of their government and the overall secrecy of their mission. ${ }^{120}$ While staying in Paris, Van Dorp's delegation may perhaps only have peered through the windows of the Bishop's Palace during the day on 28 February to observe the preparations taking place for the spectacle later that evening, just as ordinary Parisians might do whenever the French crown staged a grand festival. ${ }^{121}$ Just like those commoners, the Dutch ambassadors were not entitled to the feelings of

116 Welch, $A$ Theater of Diplomacy, esp. 11-32.

117 For a detailed analysis of the ballet, see Strong, 'Festivals', 51-55. Other festivities at the festival included banquets, balls, masquerades, and mock tournaments.

118 Oxford, Bodleian Library (hereafter BOD), Tanner 78, fols. 37v-38r, Draft letter by Derby and Stafford to Elizabeth I, Paris, 4 March 1585. On letter-dancing at the French court, see Franko, Dance as Text, 15-18.

119 BOD, Tanner 78, fol. 38r. Derby and Stafford did not specify if they had participated in the grand ball themselves.

120 However, the Florentine resident ambassador to France, Giulio Busini (b. 1530), reported to Tuscany's Secretary of State that the Dutch envoys were, in fact, invited to the king's investiture ceremony on 28 February: Busini to Vinta, Paris, 5 March 1585, in Desjardins, Négociations diplomatiques, IV, 549.

121 The Lombard choreographer Balthazar de Beaujoyeulx (1535-1587), for one, recalled how the royal guards tried to keep out 'all curious people' ('toute personne curieuse') during the rehearsals of his Balet comique de la Reine, performed on 15 October 1581 at the Louvre: Beaujoyeulx, 'Le balet Comique', fol. $7 \mathrm{r}$. 
conviviality and harmony that Derby and Stafford said they experienced while seated in the auditorium. The position of Van Dorp's train in the international community, both at the French court and within Europe at large, was quite literally that of an outsider.

By examining the European ramifications of the special embassy, this article has demonstrated how France's reception of the Dutch ambassadors in early 1585 nonetheless became a focal point of international relations, as it triggered and brought to the table the shared concerns and interests not only of the Union of Utrecht and France, but also of the Habsburg Spanish crown and its Catholic allies, as well as of England. It has been argued that Henry's calculated and pragmatic use of diplomatic ceremony played a key role in managing those relations. To facilitate Van Dorp's stay in Paris and keep the other foreign ambassadors at court moderately satisfied, the king oscillated between treating the Dutch envoys as the rebels that they were internationally made out to be, entitled to no or little ceremonial reception, and loyal diplomatic partners who enjoyed the privilege of having direct access to his person.

This transnational approach to Van Dorp's mission reveals how rather than being of exclusive interest to Dutch and Spanish authorities, the French monarchy and the wider diplomatic community in Paris took a keen interest in the outcome of the episode, as the king's acceptance of overlordship over the provinces would have inevitably altered the balance of power in Europe to Philip II's disadvantage. Close readings of historical sources by Dutch, English, and French stakeholders demonstrate that negotiations over, and protestations against, the degree of hospitality awarded to Van Dorp's train not only determined the diplomatic agency of the States-General at the French court but also that of the other deputies present. By thus bringing into focus the divided reception of the special embassy and its implications for the diplomatic manoeuvring of other European powers, and that of international relations at large, we can begin to grasp the transnational and conflictual ramifications of the States-General's diplomatic missions in the four years preceding the foundation of the Dutch Republic.

\section{Bibliography}

\section{Archival sources}

The Hague, Nationaal Archief (hereafter NA), Archief familie Van Dorp, 992, Speech by Aernt van Dorp to the Knighthood and Nobility of Holland and West Frisia, 30 December 1584.

NA, Van Dorp, 1001, Reports by Aernt van Dorp to the Gecommitteerde Raden of Holland, 15 and 22 February 1585.

NA, Van Dorp, 1008, Expenses on the embassy's journey from Boulogne to Paris, January-February 1585.

NA, Archief Staten-Generaal 1576-1588, 86D, Instructions for the special embassy to France, 3 December 1584 .

NA, Staten-Generaal 1576-1588, 88, Articles on the States-General's offer of overlordship as presented to Henry III and revised by him, 11 February 1585.

NA, Staten-Generaal 1576-1588, 89A, Letter of the Dutch embassy to the States-General, Abbeville, 19 January 1585.

London, British Library, Cotton MS Caligula E. VII, Report by Henry Stanley, Earl of Derby, and Edward Stafford to Queen Elizabeth I on their journey into France, 6 February 1585. 
Oxford, Bodleian Library, Tanner 78, Letters by Henry Stanley, Earl of Derby, and Edward Stafford to Queen Elizabeth I on their reception and entertainment in France, 4 March 1585.

\section{Printed Sources}

Aa, Abraham J. van der, and Karel J.R. van Harderwijk (eds.), Biografisch Woordenboek der Nederlanden, 21 vols. (Haarlem 1852-1878).

Aalbers, Johan, 'Factieuze tegenstellingen binnen het college van de ridderschap van Holland na de vrede van Utrecht', BMGN/Low Countries Historical Review 93 (1978/3) 412-445.

Aristotle, Nicomachean Ethics, Harris Rackham trans. (Cambridge, MA 1934).

Backer, Anne Marieke, 'La quête d'un nouvel aménagement des jardins par Marie de Brimeu, princesse de Chimay et Porcien (c. 1550-1605)', in Violet Soen and Yves Junot (eds.), Noblesses transrégionales. Les Crö̈ et les frontières pendant les guerres de religion en France, Lorraine et aux Pays-Bas (Turnhout forthcoming).

Beaujoyeulx, Balthazar de, 'Le balet Comique' by Balthazar de Beaujoyeulx, 1581. A Facsimile. Margaret M. McGowan (ed.) (Binghamton 1982).

Benedict, Philip, et al. (eds.), Reformation, Revolt and Civil War in France and the Netherlands 1555-1585 (Amsterdam 1999).

Bor, Pieter Christiaensz, Oorspronck, begin, en vervolgh der Nederlandsche oorlogen, beroerten, en borgerlyke oneenigheden, beginnende met d'opdracht der selve Landen, gedaen by Keyser Karel den Vijfden, aen sijnen Soon Konink Philippus van Spanjen, en eindigende met het einde van 't jaer MDC, 4 vols. (Amsterdam: Weduwe van Joannes van Someren, Abraham Wolfhangh, Hendrick and Dirck Boom 1679-1684).

Brood, Paul, and Raymond Kubben (eds.), The Act of Abjuration. Inspired and Inspirational (The Hague 2011).

Chatenet, Monique, La Cour de France au XVI siècle. Vie sociale et architecture (Paris 2002).

Chatenet, Monique, 'Henri III et l'ordre de la cour. Évolution de l'étiquette à travers les règlements généraux de 1578 et de 1585', in Robert Sauzet (ed.), Henri III et son temps. Actes du colloque international du Centre de la Renaissance de Tours (Paris 1992) 133-139.

Chatenet, Monique, 'Henri III au Louvre. Distribution et mobilier du logis du roi en 1585', Revue de l'Art $169(2010 / 3) 1-7$.

Cloulas, Ivan, Catherine de Médicis (Paris 1979).

Crosby, Allan James (ed.), Calendar of State Papers, Foreign Series, of the Reign of Elizabeth. Preserved in the State Paper Department of Her Majesty's Public Record Office, 23 vols. (London 1863-1950).

Crouzet, Denis, Le Haut cour de Catherine de Médicis. Une raison politique aux temps de la Saint-Barthélemy (Paris 2005).

Delen, Marie-Ange, Het hof van Willem van Oranje (Amsterdam 2002).

Descimon, Robert, and José Javier Ruiz Ibañez, Les Ligueurs de l'exil. Le Refuge catholique français après 1594 (Paris 2005).

Desjardins, Abel (ed.), Négociations diplomatiques de la France avec la Toscane. Documents recueillis par Giuseppe Canestrini, 6 vols. (Paris 1859-1886).

De Thou, Jacques-Auguste, Historiarum sui temporis libri CXXXVIII. Thomas Carte (ed.), 7 vols. (London: Samuel Buckley 1733).

De van der Schueren, Johannes B.J.N. (ed.), Brieven en onuitgegeven stukken van Jonkheer Arend van Dorp, Hr. van Maasdam, enz., 2 vols. (Utrecht 1887-1888).

Duquenne, Frédéric, L'Entreprise du Duc d’Anjou aux Pays-Bas de 1580 à 1584. Les responsabilités d’un échec à partager (Villeneuve-d'Ascq 1998).

Fazy, Henri, Genève. Le parti huguenot, et le traité de Soleure (1574 à 1579) (Geneva 1883).

Franko, Mark, Dance as Text. Ideologies of the Baroque Body (Oxford $2^{\text {nd }}$ ed. 2015).

Frowein, Jochen A., 'Die Entwicklung der Anerkennung von Staaten und Regierungen im Völkerrecht', Der Staat 11 (1972/2) 145-159. 
Geevers, Liesbeth, 'The King Strikes Back. The Spanish Diplomatic Campaign to Undermine the International Status of the Dutch Republic, 1581-1609', in Paul Brood and Raymond Kubben (eds.), The Act of Abjuration. Inspired and Inspirational (The Hague 2011) 81-95.

Gelderen, Martin van, The Political Thought of the Dutch Revolt, 1555-159o (Cambridge 1992).

Geraerts, Jaap, Patrons of the Old Faith. The Catholic Nobility in Utrecht and Guelders, c. 1580-1702 (Leiden 2018).

Giry-Deloison, Charles, 'Elisabeth Ire et le traité d'Arras de 1579', in Denis Clauzel, Charles Giry-Deloison, and Christophe Leduc (eds.), Arras et la diplomatie européenne, XVe-XVI siècles (Arras 1999) 277-297.

Giry-Deloison, Charles, 'France and Elizabethan France', Transactions of the Royal Historical Society 14 (2004) 223-242.

Groenveld, Simon, 'De institutionele en politieke context', in Jacobus Th. de Smidt et al. (eds.), Van tresorier tot thesaurier-generaal. Zes eeuwen financieel beleid in handen van een hoge Nederlandse ambtsdrager (Hilversum 1996) 54-88.

Groenveld, Simon, 'North-Netherlandish Sovereigns at Work in the First Half of the Seventeenth Century', in Randall Lesaffer, Werner Thomas, and Erik de Bom (eds.), Early Modern Sovereignty. Theory and Practice of a Burgeoning Concept in the Netherlands (Leiden forthcoming).

Groenveld, Simon, "'Verlatinge” and the Recognition of a New State', in Paul Brood and Raymond Kubben (eds.), The Act of Abjuration. Inspired and Inspirational (The Hague 2011) 65-79.

Groenveld, Simon, et al. (eds.), De kogel door de kerk? De Opstand in de Nederlanden 1559-1609 (Zutphen $2^{\text {nd }}$ ed. 1979, repr. Zutphen 1983).

Groenveld, Simon, 'Mislukte matiging, 1575-1581', in Simon Groenveld et al. (eds.), De kogel door de kerk? De Opstand in de Nederlanden 1559-1609 (Zutphen $2^{\text {nd }}$ ed. 1983) 121-140.

Groenveld, Simon, 'Spanje in de aanval, 1581-1588', in Simon Groenveld et al. (eds.), De kogel door de kerk? De Opstand in de Nederlanden 1559-1609 (Zutphen $2^{\text {nd }}$ Zutphen 1983) 141-155.

Groenveld, Simon, Pieter Wagenaar, and Frits van der Meer, 'Pre-Napoleonic Centralization in a Decentralized Polity. The Case of the Dutch Republic', International Review of Administrative Sciences 76 (2010/1) 47-64.

Haan, Bertrand, 'La Réputation du Roi d'Espagne à l'épreuve des premiers troubles aux Pays-Bas', in Béatrice Perez (ed.), La Reputación. Quête individuelle et aspiration collective dans l'Espagne des Habsbourg (Paris 2018) 115-136.

Hart, Marjolein 't, The Dutch Wars of Independence. Warfare and Commerce in the Netherlands, 1570-1680 (London 2014).

Helmers, Helmer, 'Public Diplomacy in Early Modern Europe', Media History 22 (2016/3-4) 401-420.

Heringa, Jan, De eer en hoogheid van de staat. Over de plaats der Verenigde Nederlanden in het diplomatieke leven van de zeventiende eeuw (Groningen 1961).

Holt, Mack P., The Duke of Anjou and the Politique Struggle during the Wars of Religion (Cambridge 1986). Holt, Mack P., The French Wars of Religion, 1562-1629 (Cambridge 1995).

Hooft, Pieter Cornelisz., P.C. Hoofts Nederlandsche historien. Matthijs Siegenbeek, Adam Simon, and Johannes Pieter van Cappelle (eds.), 8 vols. (Amsterdam 1642, repr. Amsterdam 1820-1824).

Horst, Daniel R., De Opstand in zwart-wit. Propagandaprenten uit de Nederlandse Opstand (1566-1584) (Zutphen 2003).

Howes, Edmund, 'The King of France's Investiture with the Garter, 20 January-12 March 1585', in Elizabeth Goldring, Faith Eales, Elizabeth Clarke, and Jayne Elisabeth Archer (eds.), John Nichols's 'The Progresses and Public Processions of Queen Elizabeth I'. A New Edition of the Early Modern Sources, 5 vols. (Oxford 2014) III, 211-221.

Israel, Jonathan, The Dutch Republic. Its Rise, Greatness, and Fall, 1477-1806 (Oxford 1995).

Japikse, Nicolaas (ed.), Resolutiën der Staten-Generaal van 1576 tot 1609, 14 vols. (The Hague 1915-1970).

Jensen, De Lamar, Diplomacy and Dogmatism. Bernardino de Mendoza and the French Catholic League (Cambridge 1964).

Jouanna, Arlette, La France du XVI siècle, 1483-1598 (Paris 2 ${ }^{\text {nd }}$ ed. 2014). 
Junot, Yves, 'Pratiques et limites de la réconciliation après les guerres de religion dans les villes des Pays-Bas méridionaux (années 1570-années 1590)', Revue du Nord 94 (2012/2) 327-346.

Knecht, Robert J., Catherine de' Medici (London 1998).

Knecht, Robert J., The French Wars of Religion, 1559-1598 (London 1996).

Koopmans, Johannes W., De Staten van Holland en de Opstand. De ontwikkeling van hun functies en organisatie in de periode 1544-1588 (The Hague 1990).

Lesaffer, Randall C.H., 'Between Faith and Empire. The Justification of the Spanish Intervention in the French Wars of Religion in the 1590s', in Martti Koskenniemi, Walter Rech, and Manuel Jiménez Fonseca (eds.), International Law and Empire. Historical Explorations (Oxford 2017) 101-122.

Lesaffer, Randall C.H., 'A Short Legal History of the Netherlands', in Hester Sanne Taekema (ed.), Understanding Dutch Law (The Hague 2004) 31-58.

L'Estoile, Pierre de, Journal de L'Estoile pour le règne de Henri III, 1574-1589. L. R. Lefèvre (ed.) (Paris: Gallimard, 1943).

Leuveren, Bram van, Forging Diplomacy Abroad and At Home. French Festival Culture in a European Context, 1572-1615. PhD diss., University of St Andrews, 2019.

Leuveren, Bram van, 'Perceptions of Privacy in Diplomatic Correspondences. Dutch and English Ambassadors at the Early Modern French Court', in Michäel Green and Lars Nørgaard (eds.), Privacy in Early Modern Correspondences (Turnhout forthcoming).

Meteren, Emanuel van, Belgische ofte Nederlantsche historie, van onsen tijden, Inhoudende hoe de Nederlanden aenden anderen gehecht ende aen Spaengien ghecomen zijn (Delft: Jacob Cornelisz. Vennecool 1599).

Mout, Marianne E.H.N., 'Het intellectuele milieu van Willem van Oranje, BMGN/Low Countries Historical Review 99 (1984/4) 596-625.

Mout, Marianne E.H.N., (ed.), Plakkaat van Verlatinge. Vertaald, ingeleid en van aantekeningen voorzien (Groningen 2006).

Müller, Pieter L., and Alphonse Diegerick (eds.), Documents concernant les relations entre le duc d'Anjou et les Pays-Bas (1576-1584), 5 vols. (Amsterdam 1889-1899).

Nys, Ernest, 'Histoire du droit international. Le Règlement de rang du pape Jules II', Revue de droit international et de législation comparée 25 (1893) 513-519.

Ochoa Brun, Miguel Ángel, Historia de la diplomacia Española, 7 vols. (Madrid 1991-2003).

Picot, Émile, Les Français italianisants au XVI e siècle, 2 vols. (Paris 1906-1907).

Osborne, Toby, Dynasty and Diplomacy in the Court of Savoy. Political Culture and the Thirty Years' War (Cambridge 2002).

Raeymaekers, Dries, and Sebastiaan Derks (eds.), The Key to Power? The Culture of Access in Princely Courts, 1400-1750 (Leiden 2016).

Soen, Violet, 'Les Limites du devoir de révolte aux Pays-Bas. Les réconciliations de Philippe de Croÿ, Duc d'Aarschot et de son fils Charles, Prince de Chimay (1576-1584)', in Violet Soen and Yves Junot (eds.), Noblesses transrégionales. Les Crö̈ et les frontières pendant les guerres de religion en France, Lorraine et aux Pays-Bas (Turnhout forthcoming).

Soen, Violet, 'Reconquista and Reconciliation in the Dutch Revolt. The Campaign of Governor-General Alexander Farnese (1578-1592)', Journal of Early Modern History 16 (2012/1) 1-22.

Soen, Violet, Vredehandel. Adellijke en Habsburgse verzoeningspogingen tijdens de Nederlandse Opstand (1564-1581) (Amsterdam 2012).

Strong, Roy, 'Festivals for the Garter Embassy at the Court of Henri III', Dance Research 1 (1983/2) 45-58.

Thomassen, Theo H.P.M., Instrumenten van de macht. De Staten-Generaal en hun archieven, 1576-1796. PhD diss., University of Amsterdam, 2009.

Tol, Jonas van, 'William of Orange in France and the Transnationality of the Sixteenth-Century Wars of Religion', BMGN/Low Countries Historical Review 134 (2019/4) 33-58.

Thiry, Steven, and Anne-Laure Van Bruaene, 'Burgundian Afterlives. Appropriating the Dynastic Past(s) in the Habsburg Netherlands', Dutch Crossing 43 (2019/1) 1-6. 
Van Bruaene, Anne-Laure, 'Spectacle and Spin for a Spurned Prince. Civic Strategies in the Entry Ceremonies of the Duke of Anjou in Antwerp, Bruges and Ghent (1582)', Journal of Early Modern History $11(2007 / 4-5)$ 263-284.

Vázquez de Prada, Valentín, Felipe II y Francia (1559-1598). Política, Religión y Razón de Estado (Pamplona 2004).

Wagenaar, Jan, Vaderlandsche Historie, vervattende de geschiedenissen der Vereenigde Nederlanden, inzonderheid die van Holland, van de vroegste tyden af, 23 vols. (Isaak Tirion: Amsterdam 1749-1789).

Welch, Ellen R., A Theater of Diplomacy. International Relations and the Performing Arts in Early Modern France (Philadelphia 2017).

Wilson, Charles, Queen Elizabeth and the Revolt of the Netherlands (London 1970). 